\title{
ISLAM DAN TAMADDUN MELAYU : Menatap Masa Depan
}

\author{
Budi Sulistiono \\ E-mail :buditebet@gmail.com \\ Universitas Islam Negeri, Syarif Hidayatullah \\ J akarta-Indonesia
}

\begin{abstract}
Islam is brought by the Prophet Muhammad Rasulullah SAW to the entire people for all aspects of life, including in social-politics. He freed people from the dark age to the light of faith. Thus, Islam is a universal, perfect, flexible, elastic, and adaptable religion to the situation and condition. It is interesting to be researched in context of historical relay of Islam missionary. Islam develops cross over the dimention of ethnics, and geograhy, and keeps developing to the various region in the world.
\end{abstract}

Keywords: Islam, civilization, and Malay.

\section{PENDAHULUAN}

Hanya dalam waktu kurang dari 100 tahun Islam dapat berkembang ke seluruh jazirah Arab dan kemudian melintasi daratan dan laut ke Afrika Utara, melalui Selat Gibraltar ke Eropa dan terus berkembang ke wilayah Timur, Asia Tengah, daratan Cina, anak benua India dan terus bergerak ke wilayah Timur hingga ke Asia Tenggara. Berikut di bawah ini ada peta. Konon peta ini ingin memberikan informasi Jalur Perdagangan baik melalui darat mau pun laut, abad ke-13 Masehi. Semoga saja melalui peta ini dapat juga dilacak data jejak Islam pasca Rasulullah saw. Selain itu, seringkali ada informasi "hubungan kegiatan perdagangan di Benua Asia, khususnya hubungan antara Arab, Persia, Cina, dan India telah tumbuh sejak awal tarikh Masehi”.

Jejak usaha dakwah Khulafaurrasyidin (632- $661 \mathrm{M})$ berlanjut ke sejumlah Khilafah membentang antara lain dari Asia Barat, Afrika, Spanyol, Asia Tengah, Asia Selatan, Asia Tenggara. Khilafah yang dimaksud, antara lain : Umayyah (Damaskus, Syria, 41-132 H / 661-750 M), Abbasiyyah (Baghdad, Iraq,132-656 H / 750-1258 M), Jeumpa (Aceh, 776 M-880 M), Rustamiyyah (Tahart, Aljazair Barat, 160-296 H / 777-909 M), Idrisiyyah (Maroko, 172-314 H / 789-926 M), Aghlabiyyah (Qairawan, Tunis, 800-909 M), Samaniyyah (Khurasan dan Transoxania, 204-395 H / 819-1005 M), Thahiriyyah (Khurasan, 205-259 H / 821-873 M), Peureulak , Aceh Timur (840-1108 M), Shafariyyah $\left(\operatorname{Sistan}^{29}\right.$, Iran 253-855 H / 867-1480 M),

\footnotetext{
${ }^{29}$ Sistan saat ini adalah Kota Provinsi.Provinsi Sistanmerupakan satu dari 31 provinsi di Iran.Provinsi ini terletak di bagian tenggara Iran, berbatasan dengan Pakistan dan Afghanistan.
} 
Budi Sulistiono, Islam Dan Tamaddun Melayu : Menatap Masa Depan

Thuluniyyah (Mesir dan Suriah, 254-292 H / 868-905 M), Zaidiyyah (Yaman, 246-680 H / 860-1281 M), Qaramithah (Arabia timur dan tengah, 281-366 H / 894-977 M), Hamdaniyyah (Syria, 293-394 H / 905-1004 M), Fathimiyyah (Mahdia, Tunis, Afrika Utara), Kairo (Mesir), 297-567 H / 909-1171 M), Ikhsyidiyyah (Mesir dan Suriah, 323-358 H / 935-969 M), Buwaihiyyah (Syiraz, Iran 945 M-1055 M), Ghaznawiyyah (Ghazni, Afghanistan, 962-1186 M), al-Murabitun (Marokko, 448 H/ 1056 M-541 H/1147 M, alMuwahhidun (Sevilla, Spanyol, 1128- 1269 M), alKhawarizmi, (Khwarizmia,Uzbekistan 1121- 1219 M), Ayyubiyyah (Mesir, 564-866 H / 1169-1462 M), Mariniyyah (Maroko, 592-956 H / 1196-1549 M), Mughal/Moghul (Agra,India,1206-1526 M), Hafshiyyah (Tunisia dan Aljazair Timur, 625-982 H / 1228-1547 M), Mamalik (Mamluk) (Mesir dan Suriah, 648-922 H / 1250-1517 M), Ilkhaniyyah (Tabriz, Iran, 1258 M - 1343 M), Samudera Pasai (di Pasai, Aceh, 1267 M).

Kehadiran sejumlah Khilafah tersebut bukti estafeta sejarah jejak dakwah islamiyah pasca wafatnya Rasulullah saw, tidak kenal berhenti. Andai saja rentetan data ini dapat diaplikasikan dalam peta, kian memperkuat dugaan, bahwa bentangan laut yang lekat dengan sebutan "Jalur Sutera", pentas dakwah islamiyah dari alHaramain (Makkah-Madinah, di Saudi Arabia), Damaskus (Syria), Baghdad (Iraq) telah melempangkan dinamika ekonomi, budaya, agama, dan politik. Banyak sumber menyebutkan bahwa jalan yang ditempuh agar sampai ke tempat tujuan ialah jalan darat atau jalan laut. Dengan kata lain, keterhubungan satu tempat ke tempat lain, dan atau satu Negara ke Negara lain secara nyata adalah suasana dinamika antar jalur maritime, dan jalan darat paling banyak digunakan sebagai jalur perdagangan.

Keterhubungan ini tidak akan pernah lahir jika tidak ada daya pikat yang dimiliki oleh satu sama lain. Ambil contoh, kehidupan ekonomi Kesultanan Jeumpa ${ }^{30}$ (Aceh, 776 M-880 M), Kesultanan Peureulak ${ }^{31}$, Aceh Timur (840-1108 M), Kesultanan Samudera Pasai (di Pasai, Aceh, 1267 M) menitikberatkan pada sektor perdagangan. Kenyataan ini karena Kesultanan-Kesultanan tersebut secara geografis terletak di jalur Pelayaran dan Perdagangan Dunia, yaitu Selat Malaka. Perdagangan merupakan sebuah proses kegiatan yang berhubungan dengan menjual dan membeli barang untuk memperoleh sebuah keuntungan. Kegiatan perjalanan mengarungi lautan dari satu tempat ke tempat lain disebut pelayaran. Perdagangan dan pelayaran menjadi kegiatan yang tidak terpisahkan dalam hubungan antarpusat perekonomian dan perdagangan antarpulau dan

\footnotetext{
${ }^{30}$ Lokasi Istana Jeumpa di Desa Blang Seupeueng sekarang disebut Cot Cibrek Pinto Ubeut. Masa itu Desa Blang Seupeueng merupakan permukiman yang padat penduduknya dan juga merupakan kota bandar pelabuhan besar, yang terletak di Kuala Jeumpa. Ibukota Kesultanan pernah pindah ke Birueun,Aceh Utara.

${ }^{31}$ Nama Peureulak, saat ini menjadi sebuah kota Kecamatan dalam wilayah administratif Aceh Timur.
} 
Al-Fikra: Jurnal Ilmiah Keislaman, Vol.14, No.2 , Juli - Desember 2015

antarnegara di masa kuno. Kegiatan perdagangan dan pelayaran tersebut telah membuka jaringan hubungan antar Nusantara dan Dunia Internasional. Keadaan itu juga sangat mendukung kreativitas masyarakatnya untuk terjun langsung ke bidang perdagangan. Melalui kekuatan politik ekonomi ummat, telah menghantarkan terwujudnya pemerintahan Kesultanan-Kesultanan itu berkembang sedemikian rupa menjadi Kesultanan yang makmur dan memiliki pertahanan yang sangat kuat.

Rentetan era ini, khusus di sebagian wilayah Nusantara adalah seiring zaman telah hadirnya Buddha dan Hindu. Bukti kehadiran Buddha dan Hindu, antara lain berdirinya kerajaan, misalnya : Raja Sanjaya memerintah di Kerajaan Mataram Kuno pada tahun 732 M. Wilayahnya sekarang ini adalah daerah Yogyakarta. Abad ke-7 M atau diperkirakan 671 M Kerajaan Sriwijaya berdiri yang tumbuh dan berkembang sampai abad dua belas, atau hingga tahun $1409 \mathrm{M}^{32}$. Pada tahun 1019 Airlangga mendirikan Kerajaan Kahuripan, dengan pusatnya di Kahuripan Sidoarjo, wilayahnya membentang dari Pasuruan (di timur) hingga Madiun (di barat), Jawa Timur. ${ }^{33}$ Dengan mencermati lokasi Kerajaan-Kerajaan Hindu-Buddha yang berada di daerah pedalaman, dan sebagian besar Kesultanan Islam berada di daerah pantai, kondisi ini memperkuat dugaan ada suasana sinergis untuk sama-sama memberdayakan JALUR SUTERA ${ }^{34}$ dan atau JALUR REMPAH-REMPAH. Istilah Jalur REMPAH-REMPAH, kini saat yang tepat untuk selalu dipromosikan karena dalam catatan sejarah Nusantara para pedagang Asing hampir pasti memborong barang-barang dagangan antara lain: garam, merica, pala, adas, cengkeh, kayu gaharu, kayu cendana, damar, kapur barus, gula tebu, pisang, pinang, kapuk, kelapa, gading gajah, kulit penyu yang terdapat di wilayah Nusantara menjadi komoditas primadona eksport dalam jaringan perdagangan Internasional.

\footnotetext{
${ }^{32}$ Kemunduran politik dan ekonomi Sriwijaya dipercepat olehekspansiberbagai kerajaan di Jawa, pertama oleh kerajaan Singosari (Singhasari). Tahun 1275 Singhasari penerus kerajaan Kediri di Jawa melakukan suatu ekspedisi militer, dalam Pararaton selanjutnya disebut semacam ekspansi dan menaklukan Bhumi Malayu yang dikenal dgn nama Ekspedisi Pamalayu. Penaklukkan berikutnya dilakukan oleh Kerajaan Majapahit, tahun 1339.Dan sejak itu Srwijaya sudah tidak disebut-sebut lagi dalam pentas politik.

${ }_{33}$ Sebelum turun takhta tahun 1042, Airlangga dihadapkan pada masalah persaingan antara kedua putranya. Maka, ia pun membelah wilayah kerajaannya menjadi dua, yaitu Kadiri dan Janggala. Peristiwa ini diberitakan dalam KitabNagarakretagama dan Serat Calon Arang, serta diperkuat oleh prasasti Turun Hyang (1044).

${ }^{34}$ Hampir pasti melalui Jalur Sutera, para pedagang Asing memasarkan Komoditi impor, antara lain: kain sutra, payung sutra, pedang, nila, lilin, belanga besi, piring, mangkuk, keramik cina, warangan, tikar pandan, merica, pala, kapur barus, gading, emas, perak dan tembaga (Wheatley, Paul. 1959, "Geographical Notes on some Commodities involved in Sung Maritime Trade" dalam J MBRAS. Vol. 32. Singapore.). Pusat-pusat perdagangan yang dihubungkan oleh Jalan Sutera di antaranya Kanton, Nanking, Kaifeng, Kasygar, Tashken, Samarkhand, dan Bukhara.
} 
Budi Sulistiono, Islam Dan Tamaddun Melayu : Menatap Masa Depan

Melalui kekuatan politik ekonomi ummat Islam telah memberikan sumbangan pengalaman yang tidak kecil antara lain dalam pentas-pentas dakwah islamiyah yang tak kenal henti, dan hasilnya dapat dibuktikan dengan munculnya sejumlah khilafah/Kesultanan di berbagai tempat yang lain, antara lain Khilafah Ghuriyyah (Herat, Afghan, 680-1342 H / 1282-1924 M), Utsmaniyah (Istanbul, Turki, 680-1342 H / 1282-1924 M), Timuriyah (Samarkand, Uzbekistan, 1370-1506), Malaka (1402 - 1511 M), Sulu (1450 M-skrg.). Data-data keberadaan sejumlah Khilafah Islamiyah ini ketika dapat diaplikasikan dalam peta di atas, kian membangun sejumlah asumsi yang diperkokoh sejumlah bukti, antara lain sebelum Islam datang dan berkembang di wilayah Asia Tenggara, Malaysia berada di jalur perdagangan dunia yang menghubungkan kawasan-kawasan di Arab dan India dengan wilayah China, dan dijadikan tempat persinggahan sekaligus pusat perdagangan yang amat penting. ${ }^{35}$ Bahkan D.G.E. Hall pernah mencatat bahwa Malaka dapat menguasai jalur trayek perdagangan yang paling menentukkan dalam sistem perdagangan internasional yang membentang dari Cina dan Maluku di Timur sampai Afrika dan laut tengah di Barat. ${ }^{36}$

Karena letaknya yang strategis di jalur lalu lintas perdagangan Internasional yang menghubungkan Laut Tengah ${ }^{37}$, Afrika, Asia Barat, Asia Selatan, dan Cina, maka Malaka berkembang pesat menjadi bandar Internasional yang besar dan makmur serta menjadi pusat pertemuan segala bangsa dan kebudayaan. Malaka juga menjadi pusat bermukimnya para saudagar Islam yang ikut berperan dalam penyiaran Islam di Nusantara.

Dari pesisir Aceh-Malaka-Sumatera, Islam kemudian menyebar ke berbagai arah Selatan ke daerah-daerah di pantai Utara Jawa seperti Surabaya, Gresik, Tuban, kemudian terus ke arah Timur hingga ke sejumlah kepulauan berikutnya, yakni Kalimantan, Sulawesi, Ternate dan Tidore di kepulauan Maluku, Nusatenggara, Bali, Papua. Islam datang di Papua tahun $1360 \mathrm{M}$ yang disebarkan oleh muballigh asal Aceh, Abdul Ghaffar. Pendapat ini juga berasal dari sumber lisan yang disampaikan oleh putra bungsu Raja Rumbati ke-16 (Muhamad Sidik Bauw) dan Raja Rumbati ke-17 (H. Ismail Samali Bauw). Abdul Ghafar berdakwah selama 14 tahun (1360-1374 M) di

\footnotetext{
35 Abdul Rahman Haji Abdullah, Pemikiran Umat Islam Di Nusantara: Sejarah dan Perkembangannya Hingga Abad Ke-19, (Kuala Lumpur: Dewan Bahasa dan Pustaka, 1990), h. 24-30.

${ }^{36}$ Hall, D.G.E. Sejarah Asia Tenggara, (Surabaya: Usaha Nasional, 1988), h. 187

${ }^{37}$ Laut Tengah, kadangkala disebut Laut Mediterania ('Mediterrania' berarti 'daratan/negeri tengah') adalah laut antarbenua terletak antara Eropa di utara, Afrika di selatan dan Asia di timur, mencakup wilayah seluas 2,5 juta $\mathrm{km}^{2}$. Pada masa lalu, laut ini merupakan jalur lalu lintas yang sibuk, memungkinkan perdagangan dan pertukaran budaya antara orang Mesir, Yunani Kuno, Romawi Kuno, dan timur Tengah.
} 
Al-Fikra: Jurnal Ilmiah Keislaman, Vol.14, No.2 , Juli - Desember 2015

Rumbati dan sekitarnya. la kemudian wafat dan dimakamkan di belakang masjid kampung Rumbati tahun $1374 .^{38}$

Mendasarkan data berupa angka-angka tahun, hingga tahun $1360 \mathrm{M}$ Islam telah datang di Tanah Papua. Data ini semakin memperkuat dugaan bahwa Usaha Dakwah Islam sudah merambah di hampir pelosok Nusantara. Ingat, di Gresik, Jawa Timur telah ditemukan makam Fatimah binti Maemun bin Hibatallah (wafat, $1086 \mathrm{M}$ ). Karenanya, taklah berlebihan untuk dikatakan bahwa keberadaan Majapahit (1293 M-1478 M) di Trowulan ${ }^{39}$, Mojokerto, Jawa Timur, adalah nyata-nyata didukung oleh peran aktif masyarakat Muslim yang telah memberikan keteladanan dalam menciptakan kekuatan politik-ekonomi Maritim yang bersinergis dengan realitas Agraris. Selain itu,proses akulturasi antara Islam dan budaya local dijadikan dalam salah satu strategi dakwah islamiyah hingga kemudian melahirkan apa yang dikenal dengan local genius. ${ }^{40}$ Data ini semakin memperkokoh anggapan bahwa Usaha Dakwah Islam tidak menghilangkan kebudayaan lokal dan tidak menggunakan kekuatan militer.

Bentangan Usaha dakwah Islamiyah dari Sabang hingga Merauke, lebih lanjut menarik untuk dicermati. Misalnya, dengan bahasa apa mereka berkomunikasi ? Dalam jejak sejarah kebahasaan Nusantara seiring usaha dakwah islamiyah, bahasa Melayu merupakan bahasa penghubung antar etnis yang mendiami kepulauan Nusantara. Semarak persebaran penggunaan bahasa Melayu terutama di kawasan kepulauan yang kini menjadi unit-unit geopolitik atau negara selain Indonesia-Malaysia-Singapore, Filipina Selatan - dikenal Moro, Thailand Selatan dikenal Patani, kian melempangkan luasnya "wilayah Kepulauan Nusantara" dalam rumpun Budaya Melayu.

Selain menjadi bahasa penghubung multietnis Nusantara, bahasa Melayu juga menjadi bahasa transaksi perdagangan Internasional di kawasan kepulauan Nusantara yang digunakan oleh berbagai suku bangsa Indonesia dengan para pedagang Asing. Kondisi nyata ini berkoinsidensi dengan suasana gerakan kemasjidan dan semisalnya (musholla, meunasah), juga gerakan kepesantrenan dan yang semisalnya (pondok, dayah di Aceh, Surau dan Minangkabau, Madrasah di Tanah Papua, semarak di hampir segala penjuru Nusantara ${ }^{41}$. Hasil konkrit dari gerakan ini "sekat-sekat antar

\footnotetext{
${ }^{38}$ Bambang Budi Utomo. 2011. Atlas Sejarah Indonesia Masa Islam. Jakarta: Kementerian Kebudayaan dan Pariwisata

${ }^{39}$ Jarak antara Gresik (kota pantai)-Trowulan $=87 \mathrm{Km}$; Tuban (kota pantai)-Trowulan $=110$ $\mathrm{Km}$

${ }^{40}$ Local Genius adalah kemampuan menyerap sambil mengadakan seleksi dan pengolahan aktif terhadap pengaruh kebudayaan asing, sehingga dapat dicapai suatu ciptaan baru yang unik, yang tidak terdapat di wilayah bangsa yang membawa pengaruh budayanya.

${ }^{41}$ Pesantren, dayah, surau, sejak sebelum hingga era penjajahan adalah satu-satunya lembaga pendidikan agama Islam yang tersedia.
} 
Budi Sulistiono, Islam Dan Tamaddun Melayu : Menatap Masa Depan

etnis" kian melebur, lahir di sana sini cendekiawan-ulama yang tidak sedikit, khusus di Indonesia hingga lahirnya bahasa kesatuan, yaitu bahasa Indonesia.

Kehadiran dayah, surau, pesantren yang didukung oleh para tokoh kharismatis ajeungan, kyai, tuan guru, teungku, juga telah berhasil memperkenalkan bahkan menciptakan kondisi berlasungnya tulisan Arab sebagai tradisi komunikasi di berbagai wilayah multi-etnis. Secara historis, tidak diketahui secara persis kapan aksara (huruf) Arab kian gencar dipakai di berbagai bahasa daerah di seantero Nusantara. Sejumlah ahli, mengatakan, bahwa hal itu terjadi seiring dengan sosialisasi Islam di wilayah Nusantara. Hasil konkrit yang dapat kita tatap di seantero Nusantara hingga saat ini adalah corak dan istilah penamaan tulisan Arab yang telah beradaptasi dengan variasi bahasa dan kegunaannya di daerah-daerah, maka lahirlah aksara Arab dalam wilayah budaya Melayu, misalnya, dikenal dengan aksara Jawi, di kalangan masyarakat Jawa dan Sunda lahir istilah aksara Pegon ${ }^{42}$, di kalangan masyarakat Aceh dikenal dengan istilah J awoe; dan sebagainya. Keberadaan aksara Jawi (bahasa Melayu dengan aksara Arab) dan Pegon (bahasa Jawa dan Sunda dengan aksara Arab) kian intens dalam wilayah Nusantara sebagaimana dibuktikan melalui khazanah tradisi penulisan berbagai dokumen dan informasi dalam bentuk manuskrip, jumlahnya melimpah yang ditulis dalam bahasa multietnis Nusantara. Di Dayah Tanoh Abee, Seulimeum, Aceh misalnya, terdapat ribuan naskah dalam bahasa Arab, Melayu, dan Aceh -ini belum termasuk naskah-naskah lainnya yang masih berada di tangan masyarakat. Data ini semakin memperkokoh anggapan bahwa Islam kian menjadi salah satu akar budaya dalam kahidupan masyarakat multietnis Nusantara.

Nilai strategis dari dakwah Islamiyah, secara estafet adalah "keteladanan" hingga mendorong terjadinya konvensi massal kepada Islam, muncul kemudian aktivitas bukan hanya di sektor perdagangan, melainkan juga dalam bidang politik, dan diplomatik. Langkah-langkah ini kemudian melahirkan asumsi bahwa keterlibatan mereka dalam varian bidang strategis itu telah berhasil memperteguh kekuatan politik dalam bentuk kesultanan/kerajaan, antara lain di berbagai wilayah pesisir, sejak Jeumpa, Peureulak, Samudra Pasai, Malaka, Aceh, Demak, Johor, Ternate-Tidore, Goa, Banten, Bima, Banjar, Selaparang dan seterusnya. Kebangkitan kerajaan-kerajaan ini, yang jelas didukung oleh faktor "rapid commercialization", pada gilirannya membantu menciptakan citra bahwa

\footnotetext{
${ }^{42}$ Sebutan kata "pegon" berasal dari kata "pegu", kemudian menjadi "pegoan", dan "pegon" yang berarti "cara melafazkan yang tidak tepat". Namun ditemui pula daerah yang bernama Pegu di Persia yang memang banyak mempengaruhi aksara Arab.
} 
Al-Fikra: Jurnal Ilmiah Keislaman, Vol.14, No.2, Juli - Desember 2015

Islam itu kuat (powerful), baik secara sipiritual, ekonomi, politik, maupun militer. ${ }^{43}$

Dalam periodesasi sejarah Indonesia, abad ke-16 sampai abad ke-18 dikenal sebagai masa pertumbuhan dan perkembangan Kesultanan Islam di bawah pemerintahan Kesultanan yang tersebar di Kepulauan Nusantara. Periode ini juga dikenal sebagai masa awal kelahiran Zaman Baru karena memiliki ciri perkembangan yang berbeda dengan sebelumnya. Keruntuhan Kerajaan Hindu-Buddha Majapahit pada sekitar peralihan abad ke-15 dan ke16 serta peningkatan aktivitas lalu lintas perdagangan Islam di jalur Samudra Hindia dan Asia Tenggara merupakan faktor terpenting yang mendukungnya. Kecenderungan baru ini mendorong meningkatnya arus kegiatan ekonomi maritim di Nusantara yang ditandai dengan tumbuhnya kota emporium (pusat dagang) dan enterpot (tempat menimbun barang di bawah pengawasan duane) yang diikuti kelahiran Kesultanan Islam di sepanjang pantai kepulauan. ${ }^{44}$

Setelah diketahui di sana-sini banyak berdiri Kesultanan Islam Nusantara, setidaknya di lokasi berdirinya Kesultanan selalu bangga menyebut dirinya, misalnya di Pontianak sebagai Kesultanan MelayuPontianak (Kalimantan Barat), di Buton sebagai Kesultanan Melayu-Buton (Sulawesi Tenggara), di Kutai sebagai Kesultanan Melayu-Kutai Kertanegara (Kalimantan Timur), di Banjar sebagai Kesultanan Melayu-Banjar (Kalimantan Selatan), di Sumenep sebagai Kesultanan Melayu-Sumenep, Madura (Jawa Timur), di Banten sebagai Kesultanan Melayu-Banten (Provinsi Banten), di Bima sebagai Kesultanan Melayu-Bima (di Nusatenggara Barat), di Ternate sebagai Kesultanan Melayu-Ternate (Maluku), di Tidore sebagai Kesultanan Melayu-Tidore (Maluku), dan sebagainya.

Mungkin saja pernyataan di atas ada yang dianggap kontroversial. Tapi boleh lah kita telusuri sejenak. Misalnya, Wujud Kesultanan adalah hasil dari bentangan waktu melalui proses panjang. Melalui proses panjang itulah sebagai warga rumpun Melayu yang telah memeluk agama Islam setidaknya sebutan Melayu identik sebagai pemeluk agama Islam. Kenyataan ini diperkuat oleh kondisi riel antara lain :

1. Upacara tradisional Melayu, meliputi keseluruhan siklus kehidupan manusia sejak dalam kandungan, kelahiran, masa kanak-kanak, remaja, dewasa, berumah tangga, hingga meninggal dunia. Semua itu diatur sedemikian rupa oleh adat yang telah disepakati sejak zaman nenek moyang orang Melayu dan diwariskan secara turun temurun hingga sekarang;

2. Tradisi penulisan memanfaatkan aksara Jawi (bahasa Melayu dengan aksara Arab) dan Pegon (bahasa Jawa dan Sunda dengan aksara Arab)

\footnotetext{
${ }^{43}$ Azyumardi Azra, Renaissans Islam Asia Tenggara, (Bandung : Rosydakarya), 1999

${ }_{44}$ Djoko, Suryo dalam Ekonomi Masa Kesultanan, Ensiklopedi Tematis Dunia Islam Asia Tenggara, (PT. Ichtiar Baru van Hoeve), Jilid 5, h. 271
} 
Budi Sulistiono, Islam Dan Tamaddun Melayu : Menatap Masa Depan

berbagai dokumen dan informasi dalam bentuk manuskrip, jumlahnya sangat melimpah yang ditulis dalam bahasa multietnis Nusantara. Menarik dicatat bahwa wilayah Nusantara yang sebagian besar masyarakatnya masih menyimpan naskah-naskah tersebut ternyata berada di wilayah Timur, antara lain di NTB, Buton, Ternate, dll;

3. Seni musik dan tari, masih bertahan warna nilai-nilai Islam di dalamnya. Contoh Saman, Seudati, Zapin, dan Rudat;

4. Seni ukir, yaitu lukisan, gambar, atau hiasan yang ditorehkan/dipahatkan pada kayu, batu, logam, dan lain sebagainya. Contoh seni ukir terdapat pada masjid Mantingan (Jepara, Jawa Tengah), ukiran kayu dari Cirebon, ukiran pada makam (Gunongan) di Madura, ukiran pada gapura makam Sunan Pandanaran/Jatinom (Klaten, Jawa Tengah), dan gapura makam Sendang Dhuwur (Lamongan, Jawa Timur);

5. Kesusastraan, di antaranya : a. Hikayat, yaitu karya sastra lama bercorak Islam yang berisi cerita pelipur lara atau pembangkit semangat. Misalnya Hikayat Raja-Raja Pasai, Hikayat Hang Tuah, dan Hikayat Jauhar Manikam. b. Syair, yaitu sajak yang terdiri atas empat bait di mana setiap baitnya terdiri empat baris. Misalnya Syair Peratun, Syair Burung Pingai, dan Syair Burung Pungguh. c. Suluk, yaitu kitab-kitab yang berisi ajaran-ajaran tasawuf. Misalnya Suluk Suka Rasa, Suluk Wujil, serta beberapa syair dan prosa tulisan Hamzah Fansuri. d. Babad, yaitu cerita yang lebih menekankan pada sejarah atau latar belakang kejadiannya. Misalnya Babad Tanah Jawi atau riwayat para nabi, Kitab Manik Mayu, dan Kitab Ambiya' yang berisi cerita dari Nabi Adam a.s. sampai Nabi Muhammad saw. e. Kitab yang berisi ajaran moral dan tuntunan hidup sesuai dengan syariat dan adat. Contoh kitab di antaranya Tajus-Salatin (Mahkota Segala Raja) karya Bukhari al Jauhari, serta Bustanus-Salatin dan Siratul Mustaqin karya Nurudin ar Raniri atas perintah Sultan Iskandar Muda II

Tragis, masing-masing Kesultanan Islam Nusantara dalam rentang perjalanannya harus berhadapan dengan bangsa Asing (Portugis ${ }^{45}$, Belanda $^{46}$, Inggris ${ }^{47}$ ), yang silih berganti datang untuk melakukan monopoli

\footnotetext{
${ }^{45}$ Tahun 1511 Portugis rebut Kesultanan Malaka; 1521 Portugis berhasil tandatangani perjanjian kerjasama dengan Kerajaan Pajajaran masa Prabu Siliwangi V. Replika perjanjian, kini masih tersimpan di Museum Nasional, Jakarta.

${ }^{46}$ Tahun 1596 Belanda berhasil memasuki wilayah Banten.Tahun 1602 VOC resmi didirikan.

${ }^{47}$ Perhatian Inggris terhadap Nusantara terinspirasi dari hasil penjelajah F. Drake singgah di Ternate pada tahun 1579.Armadanya berhasil membawa rempah-rempah dari Ternate dan kembali ke Inggris lewat Samudera Hindia. Perjalanan berikutnya dilakukan pada tahun 1586 oleh Thomas Cavendish melewati jalur yang sama. Pengalaman kedua pelaut tersebut mendorong Ratu Elizabeth I meningkatkan pelayaran internasioalnya.Inggris secara resmi menjajah Indonesia lewat perjanjian Tuntang (1811), perjanjian itu memuat tentang kekuasaan Belanda atas Indonesia diserahkan oleh Janssens (Gubernur Jenderal HindiaBelanda) kepada Inggris.
} 
Al-Fikra: Jurnal Ilmiah Keislaman, Vol.14, No.2 , Juli - Desember 2015

perdagangan hingga penjajahan. Dalam upaya menghadapi tindakan monopoli saja kehidupan sosio ekonomi, politik dan budaya masyarakat di seluruh wilayah kekuasaan Kesultanan-Kesultanan mengalami kemunduran. Bisa dibayangkan, bagaimana dan apa yang terjadi ketika tindakan "penjajahan" itu diberlakukan. Karenanya, segala daya dan upaya Kesultanan dan seluruh warganya dalam kondisi habis-habisan diutamakan untuk menentang, hingga berperang, hingga akhirnya posisi Kesultanan harus kalah dan dilenyapkan. Tapi, realitas kehidupan masyarakat rumpun Melayu yang kini sebagian besar masuk dalam wilayah Negara Republik Indonesia (NKRI) berbicara lain, hingga sekarang : jumlah ummat Islam tidak pernah berkurang, Jumlah masjid-musholla kian bertambah, lembaga pendidikan Islam (madrasah, pesantren, pondok, meunasah, surau, tidak pernah menyusut bahkan meningkat; upacara-upacara tradisional yang dibangun oleh Masyarakat Melayu masih banyak sekali yang dipertahankan, dll.

Ikhtitam

1. Masalah TAMADDUN MELAYU sebagai identitas Nusantara memerlukan langkah dan tindakan nyata untuk lebih dikenali, dicatat, difahami, sehingga ditemukan strategi nyata dalam upaya mengembangkan budaya di daerah masing-masing agar dapat dinikmati oleh anak cucu sebagai generasi nantinya.

Hasil tindakan nyata tersebut perlu dibuatkan beberapa strategi, antara lain : Pertama, menyusun kurikulum Tamaddun Melayu, yang akan diberlakukan sebagai kurikulum penyelenggaraan Kependidikan dari paling rendah hingga tertinggi.

Kedua, memasukkan kurikulum Tamaddun Melayu, yang akan diberlakukan sebagai kurikulum penyelenggaraan Kependidikan dari paling rendah hingga tertinggi.

Ketiga, pemerintah dan masyarakat bersinergis membangun pemahaman secara positif jejak tamaddun Melayu sebagai asset budaya Nusantara dalam rangka memberdayakan pariwisata.

2. Fakta sejarah membuktikan bahwa jejak ummat Islam itu kuat (powerful), baik secara sipiritual, ekonomi, politik, maupun militer harus segera dibangkitkan lagi dengan daya dukung oleh semua fihak terkait. 
Budi Sulistiono, Islam Dan Tamaddun Melayu : Menatap Masa Depan

\section{DAFTAR PUSTAKA}

Abdul Rahman Haji Abdullah, Pemikiran Umat Islam Di Nusantara: Sejarah dan Perkembangannya Hingga Abad Ke-19, (Kuala Lumpur: Dewan Bahasa dan Pustaka, 1990).

Azyumardi Azra, Renaissans Islam Asia Tenggara, (Bandung : Rosydakarya), 1999).

Djoko, Suryo dalam Ekonomi Masa Kesultanan, Ensiklopedi Tematis Dunia Islam Asia Tenggara, (PT. Ichtiar Baru van Hoeve), Jilid 5

Bambang Budi Utomo. 2011. Atlas Sejarah Indonesia Masa Islam. Jakarta: Kementerian Kebudayaan dan Pariwisata.

Hall, D.G.E. Sejarah Asia Tenggara, (Surabaya: Usaha Nasional, 1988).

Said Agil Husin al-Munawar, Al-Qur'an Membangun Tradisi Kesalehan Hakiki (Cet. III; Jakarta: Ciputat Press, 2003).

Wheatley, Paul. 1959. "Geographical Notes on some Commodities involved in Sung Maritime Trade" dalam J MBR AS. Vol. 32. Singapore. 